\title{
TRANSCOMUNICAÇÃO E O NOVO ESPÍRITO CIENTÍFICO
}

\author{
TRANSCOMUNICACIÓN Y EL NUEVO ESPÍRITU CIENTÍFICO
}

TRANSCOMMUNICATION AND THE NEW SCIENTIFIC SPIRIT

\author{
Christina Maria Pedrazza SÊGA ${ }^{1}$
}

\begin{abstract}
RESUMO: Falar de coisas imateriais como "consciência" e "alma" é, sem dúvida, enveredarse para um assunto de abrangente complexidade. Ora, por ser um tema estudado distintamente pela ciência e pela religião; ora pela tentativa de estabelecer uma conexão transdisciplinar. $\mathrm{O}$ termo "transdisciplinaridade", proposto por Basarab Nicolescu, evidencia a existência de um campo de estudo maior onde possam transitar em paridade todas as ciências. O propósito aqui é discorrer sobre a complexa comunicação que se dá entre alma e consciência e de que forma as áreas da comunicação e as outras ciências como humanas, médicas e exatas podem interagir sob o viés da transdisciplinaridade.
\end{abstract}

Palavras-chave: Comunicação; Transdisciplinaridade; Consciência; Alma.

RESUMEN: Hablar de cosas imateriales como "consciencia" y "alma" es, por supuesto, encaminarse para un asunto de abarcante complexidad. Ora por ser un tema estudiado por la ciencia y por la religión, ora por la tentativa en establecer una conexión transdisciplinar. La palabra "transdisciplinaridad" propuesta por Basarab Nicolescu, evidencia la existencia de un campo de estudio major donde pueden transitar en paridad todas las ciencias. El propósito aquí es dicurrir sobre la compleja comunicación que se da entre alma y consciencia y de que forma las áreas de la comunicación y las otras ciencias humanas, médicas y exactas pueden interagir bajo el bies de la transdisciplinaridad.

Palabras-Clave: Comunicación; Transdisciplinaridad; Consciencia; Alma.

\begin{abstract}
When we talk about immaterial things like "conscience" and "soul" it is, surely, to head for a subject of far-reaching complexity. Sometimes because is a theme

\footnotetext{
${ }^{1}$ Profa. Dra. da Faculdade de Comunicação, UNB. Pós-Doc. em Física Aplicada à Comunicação: caos, fractais e complexidade, Unesp-Botucatu-SP. Dra. em Ciências da Comunicação, Universidade Nova de Lisboa (PT). Me. em Letras, PUCCamp. Bacharelado em Publicidade e Propaganda, PUCCamp. Graduação em Letras, Unesp. Atua na área de Comunicação, principalmente nos temas: publicidade; interação social; caos, complexidade e controle na comunicação social; globalização e estética de massa (kitsch); cibercultura. Autora dos livros: Sociedade e Interação: um estudo das diferentes formas de interagir. Brasília-DF: Ed. UnB, 2011; O Kitsch e suas Dimensões. Brasília-DF: Casa das Musas, 2008. Integrante do Programa de Pós-Graduação da Faculdade de Comunicação da UNB. E-mail: segach@unb.br
} 
studied differently by science and by religion; sometimes it be an attempt to make a transdisciplinary connection. The word "transdisciplinarity", created by Basarab Nicolescu, put in evidence a great area of study in which all kinds of sciences can be connected among them. Here, the purpose is to discourse about the complex communication there is between conscience and soul, and how the areas of communication and the other sciences like human, medical and exact ones can interact among them by transdisciplinarity.

Key words: Communication; Transdisciplinarity; Conscience; Soul.

\section{INTRODUÇÃO}

No transcorrer do primeiro milênio d.C houve inúmeros desencontros entre ciência e religião, tendo o homem ficado cada vez mais confuso em busca de tantas explicações sobre sua origem e a do universo. De lá para cá, veio se mantendo a distinção polêmica e conflituosa entre religião e ciência, entre dogmas filosóficos e teológicos diante das descobertas científicas.

A dialética teórica sobre o universo começou com Copérnico (1473-1543), com a teoria do sistema heliocentrista, onde a Terra circulava ao redor do sol. Tal teoria foi sustentada por Galileu (1564-1642). No século XIX, a dialética agravou-se com Charles Darwin ao provar que o homem é descendente do macaco e, portanto, não surgiu do barro, através do sopro Divino.

Falar de coisas imateriais como "consciência" e "alma" é, sem dúvida, enveredar-se para um assunto de abrangente complexidade. Ora, por ser um tema tratado distintamente pela ciência e pela religião, ora pela tentativa de estabelecer uma conexão transdisciplinar. O termo "transdisciplinaridade", proposto por Basarab Nicolescu (1999), evidencia a existência de um campo de estudo maior onde possam transitar em paridade as ciências exatas, ciências humanas, a arte e tradição. A reunião de todos esses saberes e experiências constitui o universo holístico do conhecimento e da vida, conforme o pensamento de Pierre Weil (1990). A grande reviravolta na ciência contemporânea deu-se com a "lógica do terceiro incluído", graças a Lupasco, quando explicou que o "terceiro incluído" podia ser visto como algo complementar e não contraditório. A nova lógica ficou assim: “A, não-A e T” (terceiro incluído ou termo incluído) e com ela a noção de complexidade (Nicolescu,1999). Foi com a aceitação da complexidade que a transdisciplinaridade veio à tona, ocorrendo uma abertura sobre os diferentes níveis de realidade (SÊGA, 2009, p.143). Hoje, tanto as ciências exatas e 
humanas, como nós, seres humanos, podemos conviver com os antagonismos sem sermos contraditórios. Cabem aos estudos da complexidade e da transdisciplinaridade compreendêlos, separá-los e uni-los novamente.

Estabelecer uma conexão ou mesmo uma comunicação entre alma e consciência só é possível por meio da transdisciplinaridade por se tratar de coisas muito distintas para o conhecimento humano e científico. Para tanto, este ensaio se fundamenta no método fenomenológico, tendo como fio condutor o campo da transdisciplinaridade e seus respectivos pesquisadores a fim de se estabelecer a conexão da consciência, sob o respaldo da neurociência, e a alma sob o pilar da espiritualidade.

\section{Alma: do divino ao racional}

A ideia de alma proveniente de um sopro divino, foi relatada não apenas na Bíblia como também no pensamento grego, proposto pelo filósofo pré-socrático, Anaxímenes (570-500 a.C.), ao dizer que

o elemento ar é tão vital ao universo que por meio do movimento ele pode transformar-se na vasta variedade de coisas que constituem o nosso mundo. Assim, da mesma forma que nossa alma, sendo ar, mantém nosso corpo unido, o sopro e o ar circundam todo o mundo. (LUCE, 1994, p.29).

Para um outro pré-socrático, Heráclito (540/544-501/4 a.C), a conduta humana era muito importante e, para tanto, a alma consciente deveria seguir naturalmente para uma "trilha ascendente" seguindo uma conduta adequada no mundo. "Era dever de uma pessoa inteligente realçar essa tendência" (LUCE, 1994, p.48).

Já a concepção de espírito (nous) ou alma, para Anaxágoras, era algo infinito, eterno, que dá movimento, é diferente da matéria e é uma força capaz de organizar todas as coisas. Paralelamente, para Demócrito (460-370 a.C), "a alma era o mesmo que espírito, formada por átomos, sendo cada um deles indivisível e impenetrável porque não contém vazio" (Revista Filosofia Especial Ano 1, Nº 1, pp.39-41).

Até o século $\mathrm{V}$ aC., a alma, conhecida como psyché pelos gregos, era uma expressão da poesia, conforme relata Robinson (2010). Nos poemas de Homero, a psyché significava "força vital". Por outro lado, enquanto Anaxímenes identificava a alma com o ar, Heráclito acreditava que a alma possuía uma medida ou proporção que poderia ser aumentada. Em meados daquele século, Empédocles explicou a natureza e o destino da alma sob o ponto de vista científico, onde "a alma é um princípio de vida, essencial, atuante em percepção e pensamento" (LUCE,1994, p.65). Ainda, nesse mesmo período de época, Anaxágoras refere- 
se à alma por meio da palavra "mente", e que esta é "autômata, não se mistura com o físico e controla todas as coisas que possuem vida". Posteriormente, a alma passou a significar "agente psicológico, que pensa, planeja e está sujeito a vários sentimentos de prazer e dor" (ROBINSON, 2010, pp.15-53), embora muitos filósofos e pensadores terem atribuído a essa questão o conceito e função da mente.

Sócrates e seus predecessores tiveram dificuldade para definir a alma mas, de uma forma geral, acreditavam ser a alma "um princípio tanto intelectual quanto moral do ser humano"(Ibid.,p.65). Por fim, na última década do século V aC, Platão classifica a alma em três partes: caráter ou personalidade, motivações e o elemento racional, afirmando que a parte mais elevada de nossa alma encontra-se no racional. (LUCE, p. 105).

Paralelamente, Aristóteles compreendia a alma como julgamento ou percepção dos cinco sentidos que o homem tem - visão, audição, tato, paladar e audição - e todo julgamento pode ser certo ou errôneo para si e para os outros. Ao interpretar Aristóteles, Robinson compreende que para o antigo filósofo há uma ligação direta entre mente e alma, pois "a mente em uma palavra é pura potência" enquanto "alma é forma em potência ou em efetividade" a ponto da "mente ser uma parte da alma". Da mesma forma que Platão, Aristóteles entendia a "mente como olho da alma" (ROBINSON, 2010, pp.240-248) visto que para Platão "a alma é inteligente" (PIETRE, 1989, p. 107). E por que não questionarmos Aristóteles e invertermos sua afirmação, e entendermos que a alma é parte de uma mente, que a alma é o olho da mente e, portanto, a alma é a extensão da consciência.

\section{O campo científico da consciência e sua complexidade}

O estudo sobre consciência ganhou interesse acadêmico-científico no século XX. Antes disso, a consciência tinha sido excluída do objeto da ciência. Ela tem sido estudada de forma científica pelos campos da neurociência e da filosofia da linguagem. Searle, filósofo e linguista, admite que

a nossa visão de mundo "científica" é extremamente complexa e inclui todas as nossas teorias geralmente aceitas sobre que espécie de lugar é o universo e como ele funciona. Inclui, por assim dizer, teorias que abrangem desde a mecânica quântica e a teoria da relatividade até a teoria das placas tectônicas da geologia e a teoria do DNA (...) Pelo menos dois aspectos desta visão de mundo são fundamentais e bem estabelecidos (...) São eles a teoria atômica da matéria e a teoria evolutiva da biologia.(SEARLE, 1997, pp.127-128).

A consciência deve ser compreendida entre a relação dessas duas teorias, alega Searle, pois a consciência é uma característica biológica de determinados organismos (Ibid.,pp.137- 
139). Propondo examinar algumas relações entre consciência, comportamento e cérebro para estudar os fenômenos mentais conscientes, Searle analisa a estrutura do cérebro afirmando que

a capacidade do cérebro de causar consciência é conceitualmente distinta de sua capacidade de causar comportamento motor. Um sistema poderia ter consciência sem comportamento, e comportamento sem ciência.(SEARLE, 1997, p.104)

De certa forma, há um consenso geral de que a subjetividade faz parte da consciência. Searle enfatiza que a "consciência é subjetiva" pois não conseguimos observar a consciência do outro, além da consciência ter "temporalidade", ou seja, ela estabelece uma relação entre o espaço, tempo e sociedade.

Em outra obra, Searle (1987,pp. 77-86) argumenta que para compreendermos a estrutura do comportamento se faz necessário um conjunto de princípios que expliquem os aspectos mentais e físicos da ação. Para isso, ele elaborou oito princípios. Relatados aqui, de forma sintética, tais princípios são constituídos por ações mentais e físicas, sendo que as mentais possuem uma intenção e as físicas causam um movimento corporal. Existem ações premeditadas e espontâneas onde as primeiras resultam de um raciocínio prático. A explicação de uma ação deve ter o mesmo conteúdo que estava no pensamento da pessoa quando ela realizou a ação e que qualquer estado intencional funciona como parte de uma rede de outros estados intencionais.

De acordo com Damásio

a consciência é um fenômeno inteiramente privado, de primeira pessoa, que ocorre como parte do processo privado, de primeira pessoa, que denominamos mente. A consciência e a mente, porém, vinculam-se estreitamente a comportamentos externos que podem ser observados por terceiras pessoas (DAMÁSIO, 2000, p.29).

A consciência é, para Damásio, algo fundamental na mente humana criativa. Ele distingue consciência de mente, argumentando que

consciência e mente são também distinguíveis: consciência é a parte da mente relacionada ao sentido manifesto do self e do conhecimento. A mente não é apenas consciência, e pode haver mente sem consciência, como descobrimos em pacientes que possuem uma mas não a outra (Ibid., p.47-48).

\section{Pensamento Complexo}

Para Edgar Morin, o pensamento complexo, próprio da transdisciplinaridade, “é um pensamento da solidariedade (...) e responde ao verbo latino complexere - 'abraçar'. $\mathrm{O}$ pensamento complexo é um pensamento que pratica o abraço. Ele se prolonga na ética da 
solidariedade (MORIN, 2006, p.7-15). Então, o complexus é o "tecido que junta o todo". No seu estudo sobre complexidade, Morin elencou três instrumentos ou operadores de conhecimento: 1) sistema; 2) circularidade; 3) holograma.

O primeiro operador, o sistema, é a junção organizada de partes diferentes, assim como a sociedade é formada por indivíduos e classes sociais diferentes, constituindo uma organização social estabelecida pela cultura, linguagens, regras e leis. No sistema há a circularidade importante para a vida e para o sistema. A circularidade, formulada por Norbert Wiener, é oriunda da palavra inglesa looping, onde tudo tem uma causa-efeito-causa. Morin cita, novamente, a sociedade como exemplo circular onde os indivíduos são produtos e produtores de novas gerações. Seguindo essa linha de pensamento, podemos usar a comunicação como exemplo circular onde o emissor- receptor-emissor, indica o processo da comunicação.

O segundo operador mencionado por Morin é o hologramático onde a imagem de um holograma é diferente da imagem da fotografia, visto que no holograma um ponto corresponde a toda informação do objeto em questão. Já na fotografia, cada ponto corresponde a um ponto desse objeto. Da mesma forma ocorre com a sociedade, justifica Morin: "nós mesmos somos indivíduos que estamos dentro da sociedade, mas a sociedade, como um todo, está presente em nós desde o nascimento" (Ibid.,p.15).

Morin denomina o terceiro operador de dialógico, reafirmando o diálogo existente entre os fenômenos complexos, onde o antagônico não é contraditório mas, sim, complementar.

No processo da comunicação ocorre o mesmo. Não se pode falar de comunicação sem haver interação ou troca de sinais, linguísticos ou não-linguísticos entre o emissor e receptor. Um sinal emitido sem ser decodificado pelo receptor e desenvolvido no nível de compreensão da mensagem (feedback) não vale para a comunicação. Lembrando, aqui, que comunicação é diferente de informação propriamente conhecida. Na comunicação há interação entre as partes comunicadas e não é possível entendê-la separando as partes. O dialógico também se aplica à comunicação. Por mais que o emissor e receptor não concordem em alguns pontos da interlocução, posicionando-se antagonicamente, eles estão tentando transmitir seus pontos de vista. Portanto, há o aspecto dialógico citado por Morin, apesar de a complexidade do sistema comunicativo, aberto e sujeito aos atratores estranhos, ao caos e à reorganização. Vale lembrar que, embora a Física compreenda a entropia (caos interno) apenas em sistemas fechados, hoje, com a complexidade, já se pode incluir a entropia em sistemas abertos como, por exemplo, no sistema da comunicação. Nesse sistema estão envolvidos o conhecimento em sua abrangência, as experiências de vida e as ideologias dos interlocutores. 


\title{
Transdisciplinaridade: a grande conexão
}

Foi com a chamada "nova ciência", surgida no século $\mathrm{XX}$, que a evolução do conhecimento ganhou fôlego, incluindo ao novo pensamento científico a transdisciplinaridade, a complexidade e os estudos do caos em diferentes campos de estudo, interconectando as áreas de exatas, médicas e humanas. Dois princípios fundamentais colaboram com esse novo pensamento científico: o princípio da indeterminação ou incerteza e o princípio da complementaridade, ambos anunciados em 1927. O "princípio da indeterminação", criado por Werner Heisenberg, indicou o marco crucial da ruptura entre física clássica e física quântica. Para Heisenberg, é possível conhecer a posição exata de uma partícula - um elétron ou sua velocidade mas não as duas coisas simultaneamente (FREI BETTO, 2006, p.44). Niels Bohr também deu sua contribuição ao elaborar o "princípio da complementaridade".

Com toda essa renovação científica, os estudos da religião começaram a dialogar com a ciência, diferentemente do que ocorria nos séculos XVI a XVII.

\begin{abstract}
Naquela época, ficou estabelecido que tudo que fosse material no universo ficaria para a ciência tomar conta, uma ciência que primaria pela dissecação do todo, isto é, a divisão do todo em partes, e só assumiria como verdadeiro algo concreto que pudesse ser observado repetidamente, independentemente do observador. Por outro lado, tudo que fosse imaterial ficaria da competência da religião, cujo grupo dominante elaboraria as regras para se olhar "lá fora" e fazer as interpretações possíveis e permitidas. (GUERRINI, 2009, p.77).
\end{abstract}

Com a transdisciplinaridade vai se esvaecendo o pensamento separatista de Descartes (1650-1596) entre religião e ciência a ponto de emergir a necessidade de ligação entre ambas para um maior conhecimento do homem sobre si próprio e sobre o mundo. Dessa forma, a palavra "religião", oriunda do latim religione, adquiriu sua maior acepção latina de religare, religando todas as formas do conhecimento material e imaterial.

Hoje já é comum de se ouvir a expressão "o novo espírito científico" onde a palavra "espírito" representa o ânimo da vida, do humano, do conhecimento gnóstico e epistemológico. "Talvez seja por essa mesma razão que Einstein procurou tanto a ligação da ciência com a religião, talvez uma necessidade de quem se sentia nessa região de atuação do ser humano"(GUERRINI, 2006, p.29).

Bert Hellinger (2001), psicanalista de origem alemã, desenvolveu um trabalho sistêmico a fim de compreender a interação entre ciência e espiritualidade. Seu trabalho resultou na “Constelação Familiar Sistêmica Fenomenológica”(JACOEL, 2006, p.50).

Hellinger entende que 
a alma individual se encontra imersa na alma da família, que por sua vez encontra-se imersa em almas maiores: a raça, a cultura, a própria humanidade e o cosmos. Esse conceito de alma nos aproxima de certa maneira do conceito de Jung sobre a existência do inconsciente coletivo (JACOEL, 2006, p.53).

Paralelamente à visão de Hellinger sobre “campo da alma" está o pensamento de Sheldrake sobre "campo mórfico", referindo-se à "mente estendida" que todos nós temos.

Os campos mórficos, como os conhecidos campos da física - como os campos gravitacionais - são regiões não materiais de influência, estendendo-se no espaço e continuando no tempo. Estão localizados dentro e em torno dos sistemas que organizam. Quando qualquer sistema organizado deixa de existir, quando como um átomo se desintegra, um floco de neve derrete ou um animal morre, seu campo organizador desaparece daquele lugar (SHELDRAKE, 2011,p.11)

De acordo com Sheldrake, a idéia de que a mente é mais extensa que o cérebro é bastante antiga, remetendo às filosofias da Grécia e Índia. Entretanto, argumenta que "a visão científica convencional é de que a mente é o cérebro e a atividade mental só é atividade no cérebro físico" (Ibid., p.11). O próprio Sheldrake explica melhor a expressão "mente estendida" usando como exemplo o mecanismo da visão humana que depois de refletir a luz em um objeto, penetra nos olhos e, então, as imagens invertidas surgem na retina. Ao enxergar, a pessoa se torna consciente daquilo que vê. Porém, adianta Sheldrake, "o fato de que você se torna cônscio de sua experiência ainda é um mistério” (Ibid.,p.13).

Paralelamente, podemos também dizer que alma é uma extensão da consciência. Tanto é que, ao morrermos, deixamos de ter consciência. Para muitas crenças, a alma se desprende do corpo físico com a morte deste, da mesma forma que este corpo perde seu grau de consciência. Se esta, por sua vez, só existe dentro do cérebro e este só funciona com a energia química de seus neurotransmissores, aquilo a que chamamos de alma ou espírito nada mais é que a energia química da nossa mente estendida e, que por não dizer, da nossa consciência estendida.

De certa forma, os estudos sobre a consciência continuam um mistério para os pesquisadores do assunto, tanto que já foram escritos dois livros com o título "O Mistério da Consciência" de autores distintos. Um deles foi escrito pelo neurologista português, Antonio Damásio (2004), e o outro pelo norte-americano e filósofo da linguagem, John Searle (1998).

Se a consciência ainda é um mistério, o que dizer, então, da alma ou espírito. É difícil explicar a alma sem falar da espiritualidade "que surge como uma qualidade especial da consciência da ordem do amor, da sabedoria e da paz interior”, ressalta Carvalho (2011, pp.78), para quem a qualidade espiritual da consciência está na prática de uma espiritualidade libertadora para o ser humano, desprendida de fanatismos e julgamentos arrogantes. Muito 
antes, Annie Besant, ativista social que viveu no final do século XIX e começo do século XX, afirmou que a "espiritualidade é a percepção da unidade".

Assim, pode-se reafirmar o propósito deste texto que é compreender a alma como extensão da consciência e a interdependência entre ambas pode ser estudada pelo novo ângulo da transdisciplinaridade que, por sua vez, busca uma unidade sistêmica para o estudo e compreensão de um determinado assunto ou do mundo. Para Besant, tudo na vida tem uma consciência, até mesmo os seres inanimados. Segundo essa linha de pensamento, a transdisciplinaridade busca uma unidade espiritual consciente do cosmos. Tal unidade visa interligação e comunicação entre religião e ciência. Essa busca também está na filosofia de Krishna.

Na verdade, a ciência é a busca do homem pela descoberta da ordem que manifesta no mundo externo da matéria e da energia, e a busca religiosa é a busca da descoberta da ordem no mundo interno de nossa consciência. Na verdade não existe divisão nem antagonismo entre elas (KRISHNA, 2011, p.35)

De acordo como muitas crenças e religiões, a alma será julgada por suas ações. Da mesma forma, o indivíduo será julgado por seus atos conscientes, isentando aquele indivíduo que sofre de um distúrbio mental a ponto de afetar-lhe a consciência.

\section{CONSIDERAÇÕES FINAIS}

Por mais difícil que seja buscar um liame para a conexão entre assuntos díspares, com frequência será possível estabelecer uma comunicação transdisciplinar, se não como ponto de chegada, mas como ponto de partida para discussões polêmicas e fundamentais para o conhecimento e aprofundamento científico, acadêmico, religioso, humano e social. A intenção neste ensaio, disposto a ser contestado ou complementado pelas outras áreas ou campos de estudos, que a comunicação exerce um extensivo e intensivo papel em todas ou quase todas atividades animais e, nessas estão as humanas, desde as sociais, fisiológicas até as espirituais.

\section{REFERÊNCIAS BIBLIOGRÁFICAS}

CASTRO, Gustavo.;CARVALHO, Edgard A.; ALMEIDA, Maria C.(org.) Ensaios sobre complexidade . Porto Alegre:Sulina, 2006.

CARVALHO, Marco A.B. A descoberta da espiritualidade. Sophia. São Paulo:Teosófica. Ano 9, n 33 - Jan/Mar 2011, pp.5-9. 
DAMÁSIO, Antonio. O mistério da consciência. (trad.Laura Teixeira Motta). São Paulo: Schwarcz Ltda, 2004.

GUERRINI, Ivan.A. (org.) Nas asas do efeito borboleta - o despertar do novo espírito científico. Botucatu (SP): FEPAF, 2007.

HELLINGER, Bert. Constelações Familiares. São Paulo: Cultrix, 2001.

JACOEL, Maurice. Constelações familiares e as ordens do amor - novos paradigmas. In GUERRINI, I.A. (org.) Nas asas do efeito borboleta - o despertar do novo espírito científico. Botucatu: FEPAF, 2007.

KRISHNA, P. O que nos divide. Sophia. São Paulo: Teosófica. Ano 9, n 33 - Jan/Mar 2011, pp. 32-39.

LUCE, John V. Curso de Filosofia Grega - do século VI AC ao século III D.C . Rio de Janeiro: Jorge Zahar Editor, 1994.

MORIN, Edgar. Introdução ao pensamento complexo. Porto Alegre: Sulina, 2005.

- $\quad$ - $\quad$. Abertura. In CASTRO, Gustavo. Ensaios de complexidade. Porto Alegre: Sulina, 2006.

NICOLESCU, Basarab. O manifesto da transdisciplinaridade. $3^{\text {a }}$ ed. São Paulo: Triom, 2005.

PIETRE, Bernard. Platão -A República: livro VII. Brasília:Editora UnB, 1989. São Paulo:Ática, 1989.

ROBINSON, Thomas M. As origens da alma - os gregos e o conceito de Homero a Aristóteles. (Alaya Dullius et alii) $1^{\mathrm{a}}$ ed. São Paulo: Annablume, 2010.

SEARLE, John R. A redescoberta da mente. 1a ed. (trad. São Eduardo Pereira e Ferreira). São Paulo: Martins Fontes, 1997.

- $\quad$ - $\quad$ Mente, cérebro e ciência. (trad. Artur Morão). Lisboa-PT: Edições 70, 1987.

- $\quad$ - O Mistério da mente. (trad. André Yuji Pinheiro Uema e Vladimir Safatle). São

Paulo: Paz e Terra, 1998.

SÊGA, Christina M.P. Complexidade e caos nas ciências sociais. In GUERRINI, Ivan A. (org.) Ensaios sobre caos e complexidade: aplicações transdisciplinares em saúde e educação. Botucatu (SP): FEPAF - Fundação de Estudos e Pesquisas Agrícolas e Florestais, 2009.

SHELDRAKE, Rupert. Uma nova concepção da mente. Sophia. São Paulo:Teosófica. Ano 9, n 33 - Jan/Mar 2001, pp.10-13.

WEIL, Pierre; D’AMBROSIO Ubiratan; CREMA Roberto. Rumo à nova transdisciplinaridade - sistemas abertos de comunicação. São Paulo:Summus Editorial, 1993. 


\section{Outras Referências}

Revista Filosofia (Especial) - Grécia - Ano 1, Nº 1. São Paulo: Escala, pg.41. 